\title{
\$eduepb
}

\section{5 - Mais insumos metodológicos para a análise, a pesquisa e o desenvolvimento de Tecnologia Social}

\author{
Renato Dagnino
}

\section{SciELO Books / SciELO Livros / SciELO Libros}

DAGNINO, R. Mais insumos metodológicos para a análise, a pesquisa e o desenvolvimento de Tecnologia Social. In: Tecnologia Social: contribuições conceituais e metodológicas [online]. Campina Grande: EDUEPB, 2014, pp. 153-184. ISBN 978-85-7879-327-2. Available from SciELO Books $<$ http://books.scielo.org $>$.

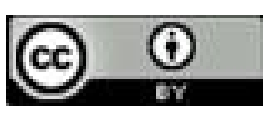

All the contents of this work, except where otherwise noted, is licensed under a Creative Commons Attribution $\underline{4.0 \text { International license. }}$

Todo o conteúdo deste trabalho, exceto quando houver ressalva, é publicado sob a licença Creative Commons Atribição 4.0.

Todo el contenido de esta obra, excepto donde se indique lo contrario, está bajo licencia de la licencia $\underline{\text { Creative }}$ Commons Reconocimento 4.0. 


\section{5 \\ Mais insumos metodológicos para a análise, a pesquisa e 0 desenvolvimento de Tecnologia Social}

\section{Introdução}

O objetivo deste capítulo é apresentar insumos metodológicos adicionais aos que venho propondo em outros trabalhos para a análise e o desenvolvimento de Tecnologia Social (TS). Mais concretamente, relacionar alguns conceitos já desenvolvidos com processos e dinâmicas que se verificam na interface entre a economia formal (ou capitalista) e aquelas porções do sistema econômico-social não inteiramente submetidos à sua lógica.

Parto da ideia de que o propósito central dos pesquisadores dos ESCTS dedicados ao campo da TS é a transformação da economia informal numa Economia Solidária (ES). Ou seja, a incorporação dos trabalhadores hoje situados na economia informal, não à economia formal (da qual foram excluídos ou nunca “incluídos”), mas sim à ES. E que esses pesquisadores visualizam como condição para tanto o desenvolvimento de TS, uma vez que sem ela não apenas a sustentabilidade (tecnológica, econômica, social, cultural, política e ambiental) dos Empreendimentos Solidários (ESs) é inviável, como é improvável o processo de completamento e adensamento das cadeias produtivas da ES que deverão conferir-lhe crescente autonomia em relação à economia formal.

Parto também da ideia de que alcançar o propósito da transformação da economia informal numa ES demanda o entendimento de dois processos. Aquele mais analisado, que tem levado à transformação da economia informal (ou não capitalista, melhor dizendo) em economia formal, ao longo da trajetória histórica de expansão do modo de 
produção capitalista, que o que, nas conjunturas de crise mais acentuada do sistema capitalista costuma levar à transformação da economia formal em economia informal.

A compreensão acerca da maneira como atividades de produção de bens e serviços antes levadas a cabo fora do circuito da economia capitalista (ou, para os efeitos que nos interessam, da economia formal) foram por ela absorvidas parece ser essencial para promover um "caminho inverso". Isto é, o caminho que poderá levar a que atividades, hoje realizadas segundo as "regras do jogo" capitalistas, possam sê-lo atendendo aos princípios da ES. O que, evidentemente, não é fácil. Em particular, porque o capitalismo, depois de terem sido geradas as condições essenciais para a sua implantação - a acumulação originária feita com muita violência - foi capaz de criar, através do "seu" Estado, a legalidade necessária para a legitimação e naturalização da propriedade privada dos meios de produção. E, dessa forma, catalisar um processo de coorganização menos violento que terminou por produzir a neblina ideológica que hoje cerca o conhecimento científico e tecnológico.

É com esse objetivo de subsidiar esse "caminho inverso" que, após retomar alguns conceitos já formulados e que podem ser usados como critérios para seleção e análise de experiências de desenvolvimento de TS, o que é feito na seção que segue, busco explorar este caminho.

\section{Conceitos que podem ser usados como critérios para seleção e análise de experiências de desenvolvimento de TS}

O primeiro conceito, já desenvolvido em outros trabalhos, é a proposta da Adequação Sociotécnica (Dagnino, 2003). Já bastante conhecido e utilizado por autores do campo da TS, como Cunca e Neder, e agências governamentais, como a Finep e a Senaes, ele pode ser entendido como segue.

Adequação Sociotécnica (AST) é um processo que busca promover uma adequação (ou reprojetamento) do conhecimento tecnocientífico, incorporado em equipamentos e insumos (hardware), formas de organização da produção (orgware), ou sob a forma intangível e mesmo tácita de modelos mentais usados para conduzir as atividades concernentes às duas formas ou conjuntos ou sociotécnicos anteriores (software). Essa adequação é entendida (e proposta), não apenas aos requisitos e finalidades de caráter técnico-econômico típicos de um dado ambiente produtivo, como é usual cada vez que se concebe o conhecimento para a produção, mas a aspectos de natureza social e ambiental até agora neles considerados 
como externalidades e, por isso, ausentes da "planilha de cálculo" (ou código técnico) utilizada no projeto de artefatos tecnológicos.

Ao contrário do que pode ser denominado adequação técnico-econômica (conhecida na América Latina como tropicalização ou engenharia reversa), a AST implica processos de desconstrução e reconstrução (reprojetamento) da tecnociência ${ }^{32}$. Isto é, processos de descontaminação da tecnociência dos valores e interesses do capital, hegemônicos nos ambientes em que é concebida e sua recontaminação com os da ES. A AST visa a adequar a tecnologia convencional (e, inclusive, conceber alternativas como indicado pelas suas sete modalidades) adotando critérios suplementares aos técnico-econômicos usuais e aplicando-os a processos de produção e circulação de mercadorias em redes de ES visando a otimizar suas implicações sociais, econômicas e ambientais.

O segundo é o próprio conceito de Tecnologia Social. Antes de expô-lo, é interessante resumir o processo que levou à sua concepção. Ele remonta ao início dos anos sessenta do século passado, quando surgiu a ideia de Tecnologia Intermediária (que originou o movimento da Tecnologia Apropriada e veio a desembocar no atual da TS) e passou a ser necessário definir o que era esta alternativa à tecnologia convencional.

Esse processo, pela variedade e incomensurabilidade dos critérios que utilizou, pelo grande número de tipos taxonômicos que gerou e pela sua escassa operacionalidade para proceder a análises capazes de levar ao desenvolvimento de tecnologia, pode ser comparado àquele que teria usado uma antiga enciclopédia chinesa em relação aos animais (Borges, 1999). Nela, os animais eram agrupados com os seguintes critérios taxonômicos: “a) os pertencentes ao imperador, b) os embalsamados, c) os domesticados, d) os leitõezinhos, e) as sereias, f) os mitológicos, g) os cachorros vadios, h) os incluídos na presente classificação, i) os que se tornam loucos, j) os inumeráveis, $\mathrm{k}$ ) os pintados com um finíssimo pincel de pelo de camelo, 1) etc. m) os que recentemente quebraram o jugo, n) os que de longe se parecem com moscas".

O conceito de TS é herdeiro de um processo com características similares. E, ao mesmo tempo, é portador de um questionamento ao de tecnologia convencional e ao modo de produção (e estilo de vida) que a engendra. Como era de esperar, portanto, o conceito de TS deriva de (e propõe) um modo de classificação não coerente com os utilizados

32 Embora prefira o uso do conceito de tecnociência (DAGNINO, 2008) ao de "Ciência e Tecnologia", utilizo por uma questão de comunicação com a literatura que trata da tecnologia, em especial a que se refere à TS, alternadamente, conforme me parece conveniente, os conceitos de tecnociência e tecnologia. 
pela visão convencional acerca da tecnologia ${ }^{33}$. Os quais, explícita ou implicitamente, estão geralmente alinhados com a manutenção do modo capitalista de produção.

Por ser baseado em aspectos sociais e políticos inerentes ao processo de construção (social) da ciência e da tecnologia, o enunciado do conceito de TS demanda esclarecimentos acerca do conceito de tecnologia como os que enuncio em seguida.

Da mesma forma que rejeito o conceito que é possível derivar das manifestações de senso comum - "a tecnologia é a aplicação da ciência (a "verdade que avança") para produzir mais, melhor, mais barato, e beneficiar a sociedade", não reconheço como válidas expressões como "alta tecnologia", "tecnologia de ponta" ou "tecnologia baseada em conhecimento". Simplesmente porque, talvez ao contrário dos que aceitam essas expressões, não consigo imaginar como seria uma tecnologia baixa, rombuda ou que não esteja baseada em conhecimento.

O mesmo ocorre em relação à distinção entre tecnologias "intensivas em trabalho" ou "em capital" ou àquela que propõe ainda a mais ingênua ou (ideologicamente) dissimulada separação entre tecnologia avançada e atrasada.

Tampouco concordo com a distinção entre "tecnologia empurrada pela ciência" e "puxada pela demanda", ou classificações como, por exemplo, a que decorre da taxonomia de setores industriais baseada em escala, em ciência etc. proposta por: Keith Pavitt (Sectoral patterns of technical change: towards a taxonomy and a theory". Research Policy, v.13, 1984, p.343-373). Também não aceita a ideia de "transferência", ou “difusão" de tecnologia, uma vez que cada vez que ocorre a aplicação de conhecimento (qualquer que seja sua natureza) para modificar um processo de trabalho se tem como resultado uma tecnologia.

A distinção que tenho proposto entre formas tecnológicas - hardware, orgware (modo de organização do processo de trabalho) e software (modelos mentais criados para viabilizar as outras duas formas) - faz aumentar o ruído que, à semelhança da taxonomia dos animais da enciclopédia chinesa, envolve a babel conceitual da tecnologia.

Finalmente, e ingressando num terreno no passado bem trilhado pelos estudiosos latino-americanos, também não me parece útil para meu objetivo a distinção entre "tecnologia nacional", "autóctone", "endógena", e "estrangeira", "importada" ou "exógena".

33 A TS e suas correlatas têm sido entendidas como "aquilo que a tecnologia convencional não é" (DAGNINO, 2009). 
A TS é um "animal" que não pode ser associado a nenhuma dessas taxonomias ou que não se enquadra em nenhum dos tipos taxonômicos que essas classificações incomensuráveis propõem. Mas, seu conceito deve ser tal que permita seu enquadramento em qualquer uma delas sem que isto implique na perda de alguma de suas características.

O conceito que proponho parte de uma ideia simples, que reconhece - de modo pragmático e ideologicamente orientado - a intencionalidade política das ações humanas. De acordo com ela, Tecnologia Social é aquela que visa à inclusão social. E é, por isso, que ela passa por cima ou cruza ortogonalmente, transcendendo, todas as classificações usuais. $\mathrm{O}$ que quer dizer que ela pode ser classificada por aqueles que preferem as taxonomias citadas como "pertencendo" a qualquer um dos tipos que elas propõem como excludentes.

No decorrer dessa revisão das taxonomias normalmente usadas para classificar (e conceituar) a tecnologia, percebi que para chegar a um conceito que fosse funcional ao objetivo de avançar no entendimento e na implementação de processos de Adequação Sociotécnica e ao propósito de transformar a economia informal numa ES, era necessário alterar radicalmente a forma como elas abordavam a questão.

O conceito de tecnologia e dos seus derivados - de tecnologia capitalista e de Tecnologia Social - a que cheguei em Dagnino (2009), decorreu também de uma insatisfação com o conceito de TS que se encontra generalizado, que a entende como compreendendo "produtos, técnicas e/ou metodologias reaplicáveis, desenvolvidas na interação com a comunidade e que represente efetivas soluções de transformação social" ou como "todo o produto, método, processo ou técnica, criado para solucionar algum tipo de problema social e que atenda aos quesitos de simplicidade, baixo custo, fácil aplicabilidade (e reaplicabilidade) e impacto social comprovado".

Essa busca teve como ponto de apoio uma perspectiva marxista e, em consequência, levou a fazer com que, por um lado, meu foco fosse concentrado na órbita da produção de bens e serviços (ou no ambiente produtivo, como tenho chamado) e não da circulação, que compreende as atividades que tornam possível o seu consumo. E, por outro, que aparecesse no conceito de tecnologia capitalista: o proprietário dos meios de produção, o processo de trabalho que ele controla e o modo como ele atua para modificar o produto gerado e para dele se apropriar.

A partir dessa perspectiva, formulei o conceito de tecnologia como o resultado da ação de um ator social sobre um processo de trabalho que ele controla e que, em função das características do contexto 
socioeconômico, do acordo social, e do ambiente produtivo em que ele atua, permite uma modificação no produto gerado passível de ser apropriada segundo o seu interesse.

Particularizando o conceito para o caso do capitalismo, tem-se o conceito de tecnologia capitalista, ou o que tenho chamado em outros trabalhos de tecnologia convencional. Ela é o resultado da ação do empresário sobre um processo de trabalho que, em função de um contexto socioeconômico (que engendra a propriedade privada dos meios de produção) e de um acordo social (que legitima uma coerção ideológica por meio do Estado) que ensejam, no ambiente produtivo, um controle (imposto e assimétrico) e uma cooperação (de tipo taylorista ou toyotista etc.), permite uma modificação no produto gerado passível de ser por ele apropriada.

Particularizando o conceito para o caso da ES a que se quer chegar, a partir da economia informal, e a um ambiente produtivo distinto daquele da fábrica capitalista, cheguei, no mesmo trabalho (Dagnino, 2009), ao conceito de TS. A TS foi então conceituada como o resultado da ação de um coletivo de produtores sobre um processo de trabalho que, em função de um contexto socioeconômico (que engendra a propriedade coletiva dos meios de produção) e de um acordo social (que legitima o associativismo) que ensejam, no ambiente produtivo, um controle (autogestionário) e uma cooperação (de tipo voluntário e participativo), permite uma modificação no produto gerado passível de ser apropriada segundo a decisão do coletivo.

Três ideias devem ser salientadas para concluir esta seção e relacionar os três conceitos básicos - TC, TS e AST - que ela aborda. A primeira é a de que cada vez que se usa a expressão AST se está fazendo referência, por inclusão, ao que "idealizadamente" se refere como desenvolvimento de TS. Isso porque, por um lado, o desenvolvimento de TS deve ser entendido como uma das modalidades possíveis de AST. E, por outro, porque a TS deve também ser entendida como o resultado de processos de AST que podem incluir modalidades (como as sete propõem o conceito) de nível de complexidade e radicalidade distintos.

Outra ideia é a que o conceito de AST, além de ser inclusivo em relação à ação ou intenção de desenvolver TS, denota uma postura distinta daquela que anima o desenvolvimento de TC. Daí o fato de me referir frequentemente à "proposta" da AST querendo com isto marcar que o processo está orientado por valores e interesses distintos (solidariedade, apropriação do excedente não vinculada à posse dos meios de produção etc.) e é conduzido por um ator social também distinto (coletivo de produtores) daquele que preside o desenvolvimento de TC. 
A terceira ideia, é que, ao associar-se à noção de "proposta", a AST enfatiza de modo realista e resignado que a concepção contra-hegêmonica à qual ele se associa e procura viabilizar no plano material, demanda, no plano econômico-produtivo concreto, mais do que uma revolução tecnocientífica (algo associável às modalidades 6 e 7 de Adequação Sociotécnica) uma adequação. Ou seja, a AST busca ressaltar o fato de que, longe de uma postura ou proposta de "reinventar a roda" ou "jogar a criança com a água do banho", que é aquela que imputa aos partidários da TS os que defendem TC, o que se pretende é aproveitar o máximo possível as soluções tecnocientíficas plasmadas na TC desconstruindo o "sistema tecnológico" as quais materializam e reconstruindo-o a partir da consideração de valores e interesses distintos daqueles que orientaram o desenvolvimento da TC.

Retomando o propósito deste capítulo, e depois de resumir conceitos que tenho desenvolvido, é possível avançar na proposição de outros critérios e balizamentos que sirvam para a seleção dos estudos de caso que se pretende realizar. E, na medida em que se mostrem adequados, para indicar caminhos de Adequação Sociotécnica para as atividades de desenvolvimento de TS.

\section{Entendendo processos: da economia informal (não capitalista) à economia formal (capitalista)}

Esta seção e a que segue tratam do contexto socioeconômico dinâmico e, por isto, mutável, em que têm lugar as iniciativas que conduzem à criação de ESs. E, por inclusão, aquelas que são o foco deste trabalho: as iniciativas de AST. Seu objetivo, vale ressaltar, é clarificar as condições a que essas iniciativas estão sujeitas e, desta forma, indicar os critérios e procedimentos que poderiam facilitar a sua viabilização. Para tanto, e por falta de uma opção mais adequada, tomou-se a perspectiva marxista para apoiar a reflexão apresentada.

Os processos que conformam esses contextos são descritos a partir de idealizações sobre como se teriam desenvolvido processos históricos esquematizados segundo essa perspectiva. A apresentação que se faz a seguir, neste caso do processo de transição da economia não capitalista para a capitalista é uma sistematização - nada original, breve, grosseira, e enviesada pelo propósito deste capítulo - de fragmentos daquilo que sobre ele pode ser desenvolvido a partir dessa perspectiva.

Em paralelo à "acumulação originária" que levou à concentração da posse da terra e ao surgimento de uma classe social cuja sobrevivência 
dependia da venda de sua força de trabalho para a classe proprietária dos meios de produção, ocorreu a concentração do conhecimento produtivo antes difundido na população.

A sociedade capitalista se diferencia dos regimes de produção anteriores no sentido em que se baseia na convivência conflituosa de proprietários dos meios de produção, de um lado, e vendedores de força de trabalho, do outro. É uma sociedade pautada na reprodução - todos os dias, de forma naturalizada - de uma relação social de produção antagônica e desigual entre compradores de força de trabalho e aqueles que a vendem. E que o fazem por terem seu acesso aos meios de produção, que lhes permitiriam auferir a totalidade do valor do trabalho que incorporam às mercadorias que produzem, vedado pelo contrato social - capitalista - vigente. Nessa sociedade que se constitui no noroeste do mundo, o propósito de garantir, naturalizar e "pacificar" essa situação de exploração engendra um terceiro ator, o Estado capitalista, que tem como objetivo primordial a reprodução dessa relação social de produção. $\mathrm{O}$ mais das vezes, é evidente, em benefício da classe dominante: os proprietários dos meios de produção que se beneficiam dessa situação.

Essa sociedade se caracteriza, também e cada vez mais, por uma tendência à propriedade privada do conhecimento. Se analisarmos a transição do feudalismo para o capitalismo, é possível observar como neste período da história ocorre uma crescente apropriação privada da terra, dos meios de produção e do excedente econômico e, também, uma cada vez maior apropriação privada do conhecimento.

Esse processo, que se inicia com o capitalismo, implicou a expropriação do conhecimento do trabalhador individual. Daquele Schumacher, cujos avôs ou bisavôs sabiam fazer um sapato desde a concepção do design até a última costura, ou do Smith cuja família de ferreiros desde há muito trabalhava com o metal. Estas pessoas que conheciam estes oficios, que até então lhes permitia seguir subsistindo em uma economia ainda não monetizada e assalariada, veem-se privadas desse saber.

O desenvolvimento do capitalismo faz com que esse conhecimento que era propriedade do indivíduo, passe, pouco a pouco, a ser codificado, sistematizado e privatizado. O neto do sapateiro, ainda, que possua o sobrenome Schumacher, já não sabe fazer sapatos. Ele foi convertido num operário "especializado" e mais "eficiente" (para o dono dos meios de produção, é claro) que só sabe furar o couro, que alguém cortou, para que outro alguém costure. E que, depois da introdução da maquinaria possibilitada pela segmentação do trabalho, irá operar a furadeira, primeiro a vapor e depois elétrica, que junto com muitas outras máquinas 
encadeadas dará a impressão de que são elas, e não os trabalhadores, as responsáveis pela geração do valor incorporado às mercadorias.

A expropriação do conhecimento do trabalhador direto, que abrangia sem distinção desde a concepção do produto (o que passou a chamar-se trabalho intelectual) até a produção de todos os seus detalhes (trabalho manual), foi possibilitada pela segmentação e hierarquização do processo de trabalho que permitiu sujeitá-lo ao controle capitalista e incrementar o ritmo do trabalho (extrair mais-valia relativa).

Acredito ser possível argumentar que a separação estrita, generalizada, sacramentada, e "sem retorno" entre trabalho intelectual e manual tem muito a ver com a sucessão, fabricada pelo capitalismo, de territórios, hoje separados ainda que fronteiriços, que vão da arte à ciência, passando pelo artesanato, pelo que se conhece como técnica e tecnologia.

Ao longo desse processo histórico, o capitalista que já era temido por concentrar a propriedade dos meios de produção passa a ser, decorridas várias gerações, respeitado: sem o "seu" saber, a produção e o salário do trabalhador não existiriam. Passa a ocorrer uma crescente naturalização da monopolização do conhecimento.

Também acredito ser possível argumentar que foi quando o sapato produzido como mercadoria - síntese de valor de uso e valor de trocapara um mercado que passava a exigir um couro mais macio, colorido, flexível, que tenha se iniciado a especialização do conhecimento. Estava "inaugurada" a indústria química. Agora, separada da de sapatos, ela iria desenvolver um conhecimento específico: a química dos couros. E, dado que isso deveria ser feito de forma econômica e confiável, "inventou-se" o laboratório. Ali se testava em pequena escala e em condições controladas, o que iria seguir um processo sistemático de scaling up que conduziria, evitando o alto custo associado à tentativa-e-erro, às inovações que se pretendia introduzir na produção. A cada vez maior separação entre conhecimento "científico" e "tecnológico", e sua segmentação interna, teria então ocorrido devido às demandas cognitivas associadas à produção. Elas contribuíram também para assegurar a hegemonia do capital na medida em que seu custo e porte crescentes.

O fato de os processos de geração de conhecimento estarem sujeitos desde o surgimento do capitalismo ao imperativo da maximização do lucro e da reprodução ampliada do capital, que exige cada vez mais a apropriação privada do conhecimento, faz com que suas características fiquem obscurecidas e naturalizadas. A exploração capitalista não aparece, ela não é visível e identificável, no processo de produção do conhecimento (capitalista); muito menos no conhecimento em si mesmo. 
E, por isso, também não se explicita a possibilidade de que um outro conhecimento (não capitalista) possa existir. Assim, o conhecimento, sobretudo o denominado científico, aquele que persegue incessantemente a "verdade", passa a ser entendido como único e universal. Não importa o quão impregnado pelos interesses capitalistas e pelos valores eurocêntricos (o que, pelo menos no início do processo de expansão do capitalismo, não é muito diferente) esteja esse conhecimento científico.

No que respeita ao âmbito tecnológico, do qual se destaca paulatinamente o científico, ocupa o lugar da "verdade", o mito da "eficiência". E no terceiro âmbito, o da produção, que anteriormente formava com os outros dois uma totalidade submetida à vontade (valores e interesses) dos produtores diretos, mas que agora é o que mais explicitamente concentra o interesse econômico do capitalista, surge um outro mito; o da "produtividade". Associado ao anterior a ponto de poder ser entendido como uma particularização, para o "recurso" força de trabalho, daquilo que genericamente vale para todos, ele se converte no critério e no padrão de eficiência da produção capitalista.

À medida que se expande o modo capitalista também se generaliza (e, mais do que isto, impõe-se) a maneira de produzir capitalista. Aquela que subordina os interesses do produtor direto que antes possuía os meios de produção com que trabalhava (e que constituía a maioria da população) à busca do lucro do capitalista. Essa maneira de produzir transforma a relação que os homens tinham entre si e com a natureza. Certas "coisas" - materiais e imateriais, naturais ou produzidas pelo homem, relações sociais e as instituições que as legitimavam etc. - passam a ser valorizadas enquanto que outras perdem o valor que antes possuíam com respeito à esfera da produção dos bens e serviços, que é a que concentra minha atenção, que satisfaziam as necessidades da sociedade.

O exemplo mais simples e conhecido talvez seja o de um minério que, embora sempre tenha existido na natureza, passa a ter valor econômico quando uma mudança tecnológica, provocada é claro por um interesse econômico, torna viável a sua extração. Outro situado num plano bem distinto é o da docilidade ou lealdade de um empregado quando o patrão adota um sistema de organização da força de trabalho que traz internalizada a coerção. Outro ainda, mas no sentido inverso é o que vem ocorrendo com o lixo doméstico que passa a ter valor econômico ou com os créditos de carbono.

O modo capitalista de produzir, num processo sutil que tende a passar tão despercebido a ponto de parecer natural, inevitável, legítimo e racional, engendra, através de um processo de coorganização ou 
auto-organização ${ }^{34}$, o seu próprio critério de eficiência valorizando algumas "coisas" e desvalorizando outras.

Apesar de muito distinta, como era de se esperar, daquela eficiência que possuía o produtor direto não submetido à lógica do capital que passa a lhe obrigar a vender sua força de trabalho, ela também se torna universal. Não há diferença, nesse sentido, em relação a tantos outros construtos epistemológicos, noções, ideias etc. que vão se alterando à medida em que transcorreu aquele processo de coorganização.

Tem atuado de modo extremamente eficaz para legitimar esse conceito de eficiência que transforma em externalidades os custos associados ao uso da natureza com o propósito de viabilizar a acumulação capitalista à síntese cosmogônica judaico-cristã, que para os efeitos da análise feita aqui, confunde-se com a eurocêntrica, que o capitalismo engendrou. De fato, ao contrário de tantas outras, originadas no velho e no novo mundo, que viam o Homem como um ser integrado na natureza, cujo bem-estar dependia de sua capacidade de com ela viver em comunhão, essa cosmogonia o entendia como um filho privilegiado de um deus que o havia criado a sua imagem e semelhança. E, por isso, era superior a todos os outros seres animados e inanimados também criados por ele. E, finalmente, estava "autorizado" a explorar a natureza para satisfazer suas necessidades e, mais do que isto, seus desejos e caprichos.

Muitos filósofos, desde Platão, têm tentado mostrar que não somos como outros animais, que vivem explorando o mundo com o olfato, meio às cegas. Essa antiga crença que vem do platonismo e do cristianismo foi renovada pelo iluminismo quando sustentou que os humanos não pertencem ao mundo natural e a humanidade poderia se livrar dos limites que cercam todas as outras espécies animais. E desde o seu surgimento como tal, a ciência tem sido usada para respaldar a ideia fantasiosa de que os humanos são diferentes de todos os outros animais e possuem uma habilidade excepcional para entender o mundo (GRAY, 2006, p.72).

Ao contribuir para fortalecer o antropocentrismo, este traço característico da nossa cultura, a ciência nos encoraja a crer que somos diferentes (e superiores) de qualquer outro animal. De que podemos entender o mundo natural e, por isso, conquistar o direito de curvá-lo à nossa vontade.

34 O pensamento ou enfoque sistêmico (CILLIERS, P. Complexity and Postmodernism: Understanding Complex Systems. London: Routledge, 1998) com conceitos como irreversibilidade, recorrência, resiliência, histerese etc. que utiliza para descrever o comportamento de sistemas complexos pode ajudar na dificílima tarefa de evidenciar as diferenças, praticamente invisíveis a olho nu, entre processos de coorganização naturais ou provocados pela vontade humana. 
Essa formulação, profundamente arraigada na cultura judaico-cristã foi integralmente incorporada ao pensamento e à práxis socialista. A ideia de que a natureza era o inimigo do homem porque o condenava à extinção e o único projeto humano de valor era uma luta titânica pela imortalidade apoiada na ciência e na tecnologia era aceita por muitos dos intelectuais que moldaram o socialismo soviético. Consolida-se, ao longo do processo de construção do socialismo soviético, a ideia de que o homem estava destinado a ter domínio sobre a natureza e a tecnologia poderia emancipar a humanidade da própria Terra. E fica impregnado no sentido comum daqueles que defendendo o ideal do socialismo eram levados a aceitar o que se veiculava como correto na experiência do socialismo real, a ideia de que a humanidade era a espécie escolhida, destinada a conquistar a Terra e derrotar a mortalidade (Gray, 2006, p.153).

No plano cognitivo, uma consequência dessa concepção, derivada da não problematização dos custos associados ao uso da natureza, foi a não necessidade de desenvolver conhecimentos científico-tecnológicos (parâmetros, relações, variáveis, modelos, algoritmos) capazes de possibilitar sua consideração no ambiente da produção de bens e serviços. Como é usual em processos de coorganização, causa e efeito se confundem neste caso. A inexistência de conhecimentos é consequência da não problematização e, ao mesmo tempo, causa da impossibilidade de, problematizando a questão dos custos associados ao uso da natureza para viabilizar a acumulação capitalista, evitar a degradação ambiental em curso.

Uma "leitura econômica" dessa concepção conduz à ideia de externalidade. Como para todos os efeitos práticos, os custos associados ao uso da natureza eram inexistentes, irrelevantes ou imensuráveis, associá-los à ideia de externalidades era absolutamente normal e legítimo. Maximizar a produção em função dos recursos "escassos" ou custosos, segundo o critério capitalista, ainda que implicando num uso intensivo e predatório de outros, que para todos os efeitos não implicavam em custos econômicos mensuráveis, era um comportamento tido como racional.

A eficiência capitalista, então, ao converter em externalidades aquilo que as sociedades anteriores entendiam e, por isto, valoravam como custos inerentes à produção, mas que deveriam ser controlados em benefício da manutenção do ecossistema que proporciona os recursos que ela emprega, leva inevitavelmente à degradação ambiental. Pode-se dizer, inclusive, que uma parte considerável da riqueza acumulada pelas classes proprietárias decorre da apropriação e uso intensivo e predatório de recursos naturais que ela realizou em detrimento da oportunidade de vida de outros seres vivos, humanos e não humanos. 
No que respeita ao terceiro mito, aquele que incide diretamente no âmbito da produção, o da produtividade, é necessário salientar como ele agrava, particularizando, as consequências do anterior, da eficiência. De fato, se o mito da eficiência atinge o conjunto da população (e das gerações futuras), o da produtividade, por se referir a um "recurso" particular, a força de trabalho, afeta, em particular, a classe trabalhadora. Maximizar a produção em função do custo do trabalho vivo, um recurso de utilização incômoda, por poder reivindicar e reagir, é também um comportamento racional. Novamente, neste caso, não importa à lógica capitalista que o modo como se utiliza a força de trabalho ameace a reprodução do sistema em que esta está inserida e que possa implicar na sua degradação.

Vale aqui ressaltar duas particularidades, dramáticas, diga-se de passagem, do recurso força de trabalho. A primeira, é que sua degradação, por ser a contrapartida de um aumento do lucro capitalista, encontra-se ideologicamente "blindada" e não é percebida como tal; pelo contrário, ela é vista e justificada como uma condição do progresso econômico. $\mathrm{Na}$ verdade, usar a força de trabalho dessa maneira abusiva é um modo de, tornando abundante este recurso pela via da manutenção de um "exército industrial de reserva", diminuir ainda mais o seu preço. Há que observar, nesse sentido, como a classe dominante e seus meios de comunicação têm logrado conscientizar a opinião pública em torno da degradação ambiental enquanto a degradação do recurso força de trabalho passa despercebida.

A segunda particularidade é que ao contrário do que ocorre em relação aos recursos naturais, o "ponto de ruptura" do recurso força de trabalho não é uma característica intrínseca e natural e sim ideológica, social e politicamente determinada. Em consequência, essa degradação pode chegar a níveis que, no caso dos recursos naturais configurariam situações de não retorno ou colapso sistêmico.

Aproximando-se do final desta extensa seção, é interessante fazer um contraponto ao que expressei acima a respeito da trajetória que teria seguido, ao longo do processo de transição do feudalismo para o capitalismo, a conformação da matriz tecnocientífica deste modo de produção mostrando uma perspectiva distinta da que informa os parágrafos anteriores. O conhecido ambientalista indiano, Claude Alvares ${ }^{35}$, assim se expressa a respeito da ciência que chamo capitalista e que ele denomina "o projeto ideológico europeu, (...) conhecido como ciência moderna".

35 No verbete Ciência, em: SACHS, Wolfgang. Dicionário do Desenvolvimento. Rio de Janeiro:, Editora Vozes, 2000. p. 55. 
Todo império é intolerante e gera violência. A arrogância da ciência com respeito à sua epistemologia levou-a a substituir, pelo seu próprio conhecimento, qualquer outra forma de saber alternativo, impondo à natureza processos novos e artificiais. Como era de se esperar, esse exercício gerou uma violência endêmica e permanente e muitos sofrimentos, à proporção que as percepções da ciência moderna se intrometeram abrupta e inadequadamente nos sistemas naturais. Assim, da mesma forma que, para abrir espaço para sua própria gente, os europeus mataram milhões de índios norte e sul-americanos e outras populações indígenas de outras regiões, e assim como sua medicina eliminou outros tipos de medicina, e suas sementes desalojaram outras sementes, também seu projeto ideológico, conhecido como ciência moderna, tentou ridicularizar e eliminar todas as outras formas de ver, de fazer e de possuir (Dagnino, 2010). (grifo meu).

Ainda com o objetivo de ilustrar como, a partir de uma perspectiva também bastante distinta da que defendo, reproduzo, a seguir, o pensamento de John Gray (2006) em Cachorros de Palha - reflexões sobre humanos e outros animais (Rio de Janeiro: Record, 2005) um livro que desde a sua publicação, em 2002, vem sendo considerado como uma síntese brilhante dos argumentos levantados pelas correntes críticas ao cientificismo.

Tentando responder a pergunta: "Por que a humanidade nunca poderá dominar a tecnologia?". Ele afirma que "Humanidade não existe. Existem apenas homens impulsionados por necessidades e ilusões conflituosas e sujeitos a todo tipo de condições debilitantes da vontade e do julgamento" Gray (2006, p. 28). E segue escrevendo que embora os "fundamentalistas científicos" afirmem que a ciência é a busca desinteressada da verdade, representar a ciência dessa forma é ignorar as necessidades humanas às quais ela serve (Gray, 2006, p. 5). Em outra passagem, vai mais além ao afirmar que

"A ciência nunca será usada prioritariamente para a busca da verdade ou para aprimorar a vida humana. Os usos do conhecimento serão sempre instáveis e corrompidos como são os próprios humanos, esses 
usam o que sabem para satisfazer suas necessidades mais urgentes - mesmo que o resultado seja a ruína (Gray, 2006, p.44).

Buscando explicar o prestígio que alcançou a ciência (e a tecnologia) na atualidade, ele escreve que "Hoje apenas a ciência apóia o mito do progresso e se as pessoas se agarram à esperança do progresso não é tanto por uma crença genuína, mas pelo medo do que possa a advir se abrirem mão dela" (Gray, 2006, p.35). Credita esse prestígio também ao fato de que os projetos políticos do século XX falharam ou ficaram muito aquém do que haviam prometido e, em contrapartida, os resultados da ciência (e da tecnologia) são diariamente experimentados e confirmados cada vez que compramos um novo aparelho eletrônico ou usamos um novo medicamento. E conclui afirmando: "A ciência nos dá um senso de progresso que a vida, a ética e a vida política não podem dar".

Num sentido oposto, ele procura explicar como a visão dominante a respeito da ciência (e da tecnologia) é capaz de deslegitimar visões alternativas. "A ciência tem o poder de silenciar hereges". Segundo ele, "a ciência é, hoje, a única expressão que pode reivindicar autoridade. Como a igreja no passado, ela tem o poder de destruir ou marginalizar pensadores independentes" (Gray 2006, p.35). E isso, sutilmente, sem estabelecer, a priori, padrões muito rígidos. Ao censurar pensadores que se afastam excessivamente dos paradigmas correntes, ela alimenta a ilusão de que existe apenas uma única visão de mundo legítima.

Num outro contexto, e retomando a analogia entre ciência e religião colocada por outros autores, Gray afirma que:

Hoje, para a maioria da humanidade, a ciência e a tecnologia são a materialização de "milagre, mistério e autoridade". A ciência promete que as mais antigas fantasias humanas serão finalmente realizadas. Como o cristianismo no passado, o moderno culto da ciência vive da esperança de milagres. Mas pensar que a ciência pode transformar a sorte humana é acreditar em magia (Gray, 2006, p.139).

E completa dizendo: "A ciência é um lugar onde nos refugiamos da incerteza. Ela nos promete em alguma medida produzir o milagre de nos livrar de pensar, enquanto as igrejas passaram a ser lugares de proteção e refúgio para as dúvidas (Gray, 2006, p.36). 
Concluindo esta incursão no pensamento crítico não marxista da ciência e da tecnologia, reproduzo uma provocativa frase de Gray a respeito da comunidade de pesquisa:

Como os cristãos dos tempos antigos, os cientistas estão presos às malhas do poder; lutam para sobreviver e ter sucesso; suas visões de mundo são um amontoado de crenças convencionais. A ciência não pode trazer "milagre, mistérios e autoridade" para a humanidade, quando mais não seja porque - como no caso daqueles que serviram para a igreja no passado - seus servos são extremamente humanos (Gray, 2006, p.141).

Para encerrar essa caricatura acerca de como o desenvolvimento do capitalismo condicionou o que temos chamado de ciência e tecnologia, faço duas considerações.

A primeira aproveita a deixa da última citação de Gray, para lembrar a contribuição inestimável que deram as elites ilustradas situadas nos espaços onde se produzia e cultuava o "saber" para legitimar pela via ideológica o processo através do qual, o conhecimento científico capitalista logrou impor sua "verdade". Processo que demandou, inclusive, fazer desaparecer aquilo que produziam as sociedades antes existentes, e que era compartilhado quase sem exceção pelos seus integrantes. O mesmo não ocorre com o conhecimento tecnológico. Nesse caso, o processo de coerção foi bem menos sutil.

A segunda consideração nos remete de volta ao presente para nos darmos conta de como esse processo, que é muito antigo, vem se radicalizando ao ponto de que hoje $70 \%$ das pesquisas que se fazem, no mundo, são feitas em empresas (e 50\% nas transnacionais). E, também, de como esta associação de dois termos - ciência e tecnologia - é cada vez menos apropriada para fazer referência ao conhecimento que essa pesquisa produz. O conceito de "tecnociência" parece mais adequado. Dentre outros motivos, porque não é apenas no plano da prática concreta que a distinção entre eles se mostra cada vez mais sutil: hoje os países de capitalismo avançado não fazem mais política científica e tecnológica, mas sim política de tecnociência; claro que em benefício das empresas.

O corte espacial - ciência se faz na universidade, e tecnologia se faz nas empresas - já não têm sentido. As universidades realizam desenvolvimento tecnológico, e as empresas fazem pesquisa científica. Uma das empresas importantes do setor de informática já teve dez prêmios Nobel, 
na sua folha de pagamento, dedicando-se a fazer pesquisa. Isso nos faz revisar a distinção entre a ciência e a tecnologia e dizer que a tecnologia é ciência aplicada, ou que a ciência precede a tecnologia, ou que a ciência pode ser utilizada, como tecnologia, para o bem ou para o mal.

O corte temporal tampouco sobrevive. No passado, as ideias novas demoravam muito tempo para chegar ao mercado; as invenções demoravam muito também para se transformar em inovações. Atualmente, no entanto, esse tempo vem se reduzindo até o ponto de que hoje somente as regulações - como as que estabelece o Departamento de Saúde norte-americano, que exige que uma nova molécula seja testada, durante algum tempo, retardando sua entrada no mercado farmacêutico - fazem com que as invenções não se transformem mais rápido em inovações.

Expostos esses dois cortes - espacial e temporal - porque já não são válidos, é hora de passarmos a entender a dinâmica de produção do conhecimento cada vez mais como produção de "tecnociência". A ideia de que para a resolução de problemas sociais - para a inclusão social - é necessária uma tecnociência capaz de incorporar os valores e interesses dos segmentos excluídos ganha, então, plausibilidade. Se aceitamos que a tecnociência existente guarda, internalizados, os valores e interesses do capital, temos que aceitar que uma tecnologia social, para que possa resolver problemas sociais, para que possa alavancar a inclusão social, terá que ser contaminada por outros interesses e outros valores. Essa é uma das ideias centrais do que tenho defendido.

Para concluir esta seção e com uma ajuda de memória, resumo de forma "telegráfica" os eventos e as características do processo que nos levou da economia informal (não capitalista) à economia formal (capitalista):

- acumulação primitiva;

- assalariamento;

- legalização da propriedade privada dos meios de produção;

- segmentação e hierarquização do trabalho;

- expropriação do conhecimento do trabalhador direto;

- naturalização da propriedade privada (temor à respeito);

- naturalização da separação trabalho manual x intelectual,

- sistematização/segmentação do conhecimento imposta pela produção;

- autonomização do conhecimento em relação à produção;

- fetichização da propriedade privada (respeito à idolatria). 


\section{Entendendo processos: da economia formal (capitalista) à economia informal (não capitalista)}

Esta seção e a que segue tratam do contexto socioeconômico dinâmico e, por isto, mutável, onde têm lugar as iniciativas que conduzem à criação de ESs. E, por inclusão, aquelas que são o foco deste trabalho: as iniciativas de AST.

Os processos que conformam esses contextos são descritos a partir de idealizações sobre como teriam eles transcorrido e sido esquematizados segundo uma perspectiva marxista. A apresentação que se faz a seguir, neste caso do processo de transição da economia não capitalista para a capitalista é uma sistematização - nada original, breve, grosseira, e enviesada pelo propósito deste trabalho - de fragmentos daquilo que sobre ele pode ser desenvolvido a partir dessa perspectiva.

Observando a relação entre a economia formal e a informal é fácil verificar que ela envolve a troca de insumos (matérias-primas) e produtos, por um lado, e capital e mão de obra, por outro. Tal como mostra a figura 1 que segue, privilégio para o entendimento da forma como se verifica, no tempo, essa relação, ou a forma como se processa a dinâmica capitalista que condiciona os fluxos de capital entre elas.

Figura 1 - Sociedade/Economia

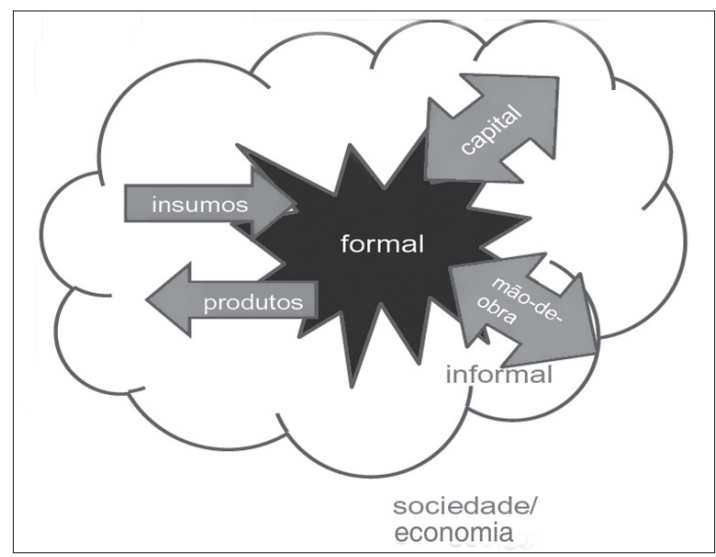

É possível individualizar, na dinâmica capitalista, situações típicas limites e gradientes - associadas (ou desencadeadoras) ao trânsito do capital entre a economia formal e a informal. Elas seriam as responsáveis por "regular" processos que, idealmente, ter-se-iam verificado ao longo da expansão do capitalismo. Primeiramente no sentido da economia formal para a informal, mas que em função de mudanças ou gradientes 
relacionados a algumas variáveis dessa dinâmica podem ocorrer no sentido inverso.

A tipologia está composta por seis situações típicas:

1. Limite econômico: o capital se vai localizando em segmentos (ou atividades) econômicos com taxas de lucro decrescente. Os com taxas superiores ficam reservados para os maiores, com maior poder político etc.). Os não atrativos permanecem na periferia do capitalismo (economia informal).

2. Limite político: costumes e práticas culturalmente arraigadas impedem a legalização da propriedade privada dos meios de produção em alguns segmentos ou atividades (informais) e, assim, protegem-nos da penetração do capital.

3. Limite do econômico x político: o balanço entre lucratividade esperada e custo político de ingressar em "espaços não capitalistas" (mais afastados ou menos acessíveis) leva a que a economia informal possa subsistir até mesmo no espaço urbano.

4. Gradiente tecnológico: a disponibilidade de uma nova tecnologia capaz de tornar rentável um "recurso natural" (economia informal) transformando-o num "recurso econômico" é um determinante da lucratividade esperada e tende a provocar a expansão do capital para explorá-lo.

5. Gradiente regulatório ou de mercado: uma mudança na relação de preços do trabalho vivo (salário) x trabalho morto (meios de produção, matéria-prima) é um determinante da lucratividade esperada e provoca a expansão ou retração do capital.

6. Gradiente político: uma mudança na correlação de forças políticas, sobretudo se incide na estrutura legal, provoca a expansão ou retração do capital (para a economia informal)

Nos itens que seguem, analiso dois casos - o fenômeno "catadores" e a TS a ele associada, e o do artesanato - que permitem ilustrar o que foi explicado acima e mostrar como se poderia aplicar essa tipologia para aumentar nossa capacidade de entender e desenvolver TS.

\section{Uma atividade que se "informalizou": o fenômeno "catadores" e a TS a ele associada}

Há décadas, a coleta de lixo domiciliar, no Brasil, era um serviço executado pelo poder público. Posteriormente empresas privadas foram contratadas para tanto. O lixo depositado em lixões ou aterros sanitários 
(?), com o aumento da miséria, passaram a ser "visitados" pelos excluídos à procura de restos de comida e materiais que pudessem ser usados ou comercializados. Com o agravamento da exclusão social, os excluídos não puderam seguir esperando que o lixo fosse depositado nos lixões para apropriar-se do que era descartado. Uma parcela deles passou a coletar o lixo nas residências, empresas etc. de modo a evitar que, ao serem depositados nos lixões, os materiais de maior valor terminassem sendo apropriado pelos que anteriormente os "visitavam". Em função disso e devido às vantagens que o novo arranjo apresentava para o capital, a coleta de lixo, uma atividade que pertencia ao setor formal da economia brasileira e era, por isto, regulada pelos mecanismos formais, passou, então, como muitas outras ocupações, a pertencer à economia informal e a ser regida pelos seus mecanismos informais.

O que não significa que o lixo não seja uma mercadoria e o trabalho dos catadores não esteja integrado ao processo acumulação de capital. O fato de o lixo ser praticamente o único meio de produção necessário para a atividade dos catadores e dele não ser (até agora, pelo menos) uma propriedade privada não implica que o fenômeno "catadores" não esteja subordinado à dinâmica capitalista. O arranjo sociotécnico "catadores" tem-se mantido como parte da economia informal porque seu produto chega como insumo à economia formal com um preço menor do que aquele que uma empresa privada poderia praticar.

Como ressalta Bosi (2008), o fato de o catador ser um desempregado de baixa escolaridade e faixa etária elevada, destituído de "empregabilidade" para a economia formal, é justamente o que o qualifica para esse tipo de trabalho. Ao contrário, a organização dessa atividade é realizada pelos interessados na compra, reciclagem e comercialização do material coletado pelos catadores. E não há como negar que o aproveitamento desse crescente número de trabalhadores, excedentes porque não qualificados para o "mercado", é uma forma de reincorporá-los ao circuito de acumulação do capital.

Adicionalmente, convém lembrar que a par do aproveitamento das propriedades físicas e químicas do material, descartado como lixo e coletado, a reciclagem recupera o valor da força de trabalho que foi utilizado para sua produção e que nele permanece incorporado. Diferentemente dos primitivos "visitantes" dos lixões que ali iam buscando recuperar o valor de uso dos materiais, a coleta-reciclagem recupera o valor de troca das mercadorias.

$\mathrm{Na}$ atualidade, existe no Brasil, inclusive, uma tecnologia muito particular de coleta e reciclagem de lixo. Mediante ela, é possível que nosso 
país se situe em segundo no ranking internacional, seguindo o Japão, de reciclagem de objetos de alumínio (em especial latas de cerveja) e em terceiro lugar em reciclagem de plásticos.

Todos nós conhecemos a tecnologia de coleta de lixo aqui empregada e o modo como ela se conecta com a economia formal. Ela pode ser caricaturada pela frase que ouvimos nas festas públicas: "Óiaí, patrão, já terminou a cerva? Posso levá a latinha?”. Mas poucos pesquisadores, mesmo os que trabalham com ES e TS, dão-se conta que ela e a de reciclagem a ela associada só é possível porque esses objetos são lixo. É porque existe uma propriedade coletiva (ou não privada) dos meios de produção que leva ao desenvolvimento de uma tecnologia muito distinta da utilizada, por exemplo, no Japão. Uma tecnologia que só existe devido ao fato da taxa de lucro associada à atividade realizada pelos catadores ser menor do que aquela que o capital encontra em outros setores da economia. Fato que a protege (no sentido de que se criam barreiras à entrada) da concorrência das tecnologias de coleta e reciclagem empregadas em outras partes do mundo. Simetricamente, essa tecnologia seria inviável num contexto japonês. De fato, se os catadores que a utilizam fossem pagos de acordo com a legislação trabalhista japonesa (ou mesmo brasileira) ela seria proibitiva.

A tecnologia brasileira, dadas as condições de exclusão vigentes no país, é competitiva em relação àquelas. É a superexploração do trabalho o que possibilita que o "atravessador" ao comprar o material catado esteja pagando não pelo material (alumínio, por exemplo) que ele contém, mas pelo trabalho vivo informal a ele incorporado pelo catador. Assim, sem que tenha existido propriamente uma intenção de desenvolver uma TS, existe uma tecnologia alternativa e competitiva (!) àquela usada nos países avançados.

A existência dessa tecnologia parece corroborar o expressado por Bosi (2008), quando escreve que

“[...] não se trata apenas de reconhecer a organização capitalista do trabalho 'informal', mas de perceber como esse tipo de organização também 'ressignifica' e condiciona as experiências e as práticas dos diversos sujeitos implicados nesse processo.

Depois de explicar o trânsito da atividade de coleta e reciclagem do setor formal para o informal e mostrar como o desenvolvimento de uma tecnologia adaptada ao ambiente socioeconômico vigente tende a consolidar a mudança, poder-se-ia investigar que alterações associadas 
àquelas seis situações típicas poderiam gerar um movimento no sentido contrário, de desestabilização e eventual reversão.

\section{Uma atividade que não se "formalizou": o artesanato}

Depois de analisar uma atividade que se "informalizou", vamos analisar uma que permaneceu na economia informal: o artesanato.

É óbvia a ideia de que quanto mais pobre a comunidade em que se pratica o artesanato (e o seu entorno imediato), mais dificil é manter vivas as formas de produção artesanal. A pobreza impede que o não artesão pobre adquira o artesanato. E existem pelo menos dois agravantes que condenam o artesanato a desaparecer: o preço menor das mercadorias similares produzidas pelo setor formal e o efeito demonstração que a posse de produtos modernos da economia formal exerce sobre os consumidores. Sem falar que essas mercadorias, que inicialmente eram similares às que eram produzidos na economia não capitalista, foram incorporando tantas características novas (o que frequentemente não implicava que fossem necessárias ou convenientes) que passaram a ser consideradas novos produtos. Esse processo, cuja abrangência foi do ambiente doméstico até aquele em que se realizavam grandes obras de infraestrutura e, por isso, foi muitas vezes dramático e com consequências penosas para os mais pobres e desastrosas para todos, passa atualmente despercebido em função da naturalização que o acompanhou.

Os artesanatos que sobrevivem, fazem-no porque logram obter sucesso entre os ricos; que, em geral, encontram-se a uma certa distância das comunidades artesanais pobres. Outros permanecem valorizados pelos pobres, porque são insubstituíveis ou muito melhores ou mais bonitos do que seus similares produzidos na economia formal.

Processos no sentido inverso, que vão da economia formal para formas de produção artesanal, ocorrem entre os ricos em situações de escassez muito específicas de algum produto, ou em função de movimentos de defesa contra efeitos negativos associados aos produtos da economia formal (alimentação com vegetais livres de agrotóxicos, medicina tradicional) que levam à sua substituição por bens produzidos, algumas vezes, pelas próprias famílias. Entre os pobres, ao invés de exceção, o uso de materiais que substituem os de maior preço usados pelos ricos é a regra. Provavelmente onde isso é mais evidente é na moradia. Também, possivelmente, parece ser na esfera da alimentação, onde a comida tradicional é substituída, por mães que querem agradar os filhos, pelos salgadinhos, onde é mais notório o processo inverso. 
Nos países de capitalismo avançado, houve casos em que o artesanato, fertilizado com outras capacidades e habilidades dominadas por comunidades que se mantiveram na economia informal (claro que de outra natureza), resistiu à expansão dos produtos da economia formal. Em muitos outros casos, as capacidades e habilidades que entranhavam o artesanato foram a origem de cadeias produtivas que resultaram na sua incorporação com vantagens (em geral transitórias, é certo, até que o processo de expropriação do conhecimento tivesse lugar) à economia formal.

De forma geral, é possível observar que foi no setor agrícola, onde a propriedade privada dos meios de produção não se generalizava tão rapidamente, que se mantiveram por mais tempo as formas de produzir baseada na produção familiar, no associativismo e nas tecnologias com elas coerentes. E é pela sobrevivência (ou, pelo menos, a memória) de formas de propriedade não privada dos meios de produção, que seguem sendo no setor rural onde até hoje se concentram, de maneira avassaladora, as propostas de adoção de tecnologias distintas da tecnologia convencional (ou capitalista). E onde o surgimento e sobrevivência de formas de produzir alternativas à forma hegemônica são possíveis. É porque ali ainda existem, senão a propriedade coletiva, os vestígios que ela deixou em termos da possibilidade de trabalho cooperativo. No meio urbano, é só nas fábricas recuperadas, ou nas cooperativas de catadores de materiais recicláveis que adicionam o valor de sua força de trabalho a um capital constante com um valor praticamente nulo, como é o caso do lixo, onde formas de produzir alternativas são possíveis.

É digno de destaque e reflexão o fato de que a colocação acima, que parece uma derivação evidente da abordagem de cunho marxista que se está seguindo, parece ser um "ovo de Colombo" no âmbito dos resultados de pesquisa da área de ES e de TS.

Para concluir, ressalto algo conhecido: em muitos países latino-americanos, ainda que talvez em menor medida no Brasil, existe conhecimento "popular" difundido entre as populações excluídas capaz de originar cadeias produtivas na ES. A questão é como identificá-lo e mobilizá-lo? A seção que segue pretende ser uma contribuição para a abordagem dessa questão.

\section{Concebendo processos: da economia informal à Economia Solidária (e à Tecnologia Social)}

Nesta seção, vou tentar explicar como um caminho inverso ao seguido "naturalmente" pelo capitalismo, na sua trajetória de expansão, poderia 
ser emulado racionalmente para promover o trânsito da economia informal para a ES, que é a motivação principal de nosso livro. Retomo, por isso, o dito inicialmente a respeito do princípio de economicidade que deve orientar o trabalho de pesquisa lembrando que são situações em que é possível materializar a combinação entre as potencialidades de comunidades excluídas e problemas locais, aquelas que devem concentrar nossa atenção. Isso porque é a análise dessas situações que nos poderá auxiliar a identificar caminhos genéricos de Adequação Sociotécnica passíveis de serem seguidos em atividades de desenvolvimento de TS.

As figuras que seguem procuram explicar um procedimento concebido para ser utilizado para identificar e operacionalizar situações visando ao desenvolvimento de TS. Cabe ressaltar que esse procedimento só terá sentido e alcançará bom resultado se ele for claramente entendido pela comunidade em que se pretende atuar e se for possível contar com sua efetiva participação.

$\mathrm{Na}$ figura 2, que segue, identifico uma comunidade "i” qualquer inserida na economia informal (ou já integrante da ES), relacionada com um "lado da oferta", associado às "vantagens cooperativas" que possui, e um "lado da demanda", associado a demandas materiais por bens e serviços.

Essa comunidade, por construção, possui, em função da sua história pregressa, "vantagens cooperativas" (potencialidades, habilidades, saberes de natureza genérica ou específica e que podem ser utilizados em ESs na produção de bens e serviços para o atendimento de demandas materiais). $\mathrm{E}$, do lado da demanda material, deve enfrentar dois desafios. O primeiro é o da produção de bens e serviços necessários à subsistência dos integrantes da comunidade e dos próprios trabalhadores envolvidos com ESs e dos insumos neles utilizados.

O segundo desafio é o da produção de bens e serviços de uso cidadão (coletivo ou público) necessários ao conjunto da população cuja oferta é de responsabilidade direta ou indireta do Estado, que não precisam ou não devem "passar pelo mercado" e podem ser produzidos por ESs. Benefícios sociais de vários tipos, que incluem vantagens econômicas associadas ao custo de produção e distribuição; sociais, associadas à ampliação de oportunidades de trabalho e renda para os excluídos; morais, associadas ao seu empoderamento e recuperação de sua autoestima; ambientais, associadas à desconcentração e escala produtiva e ao uso de tecnologias limpas etc. 
Figura 2 -Vantagens Cooperativas

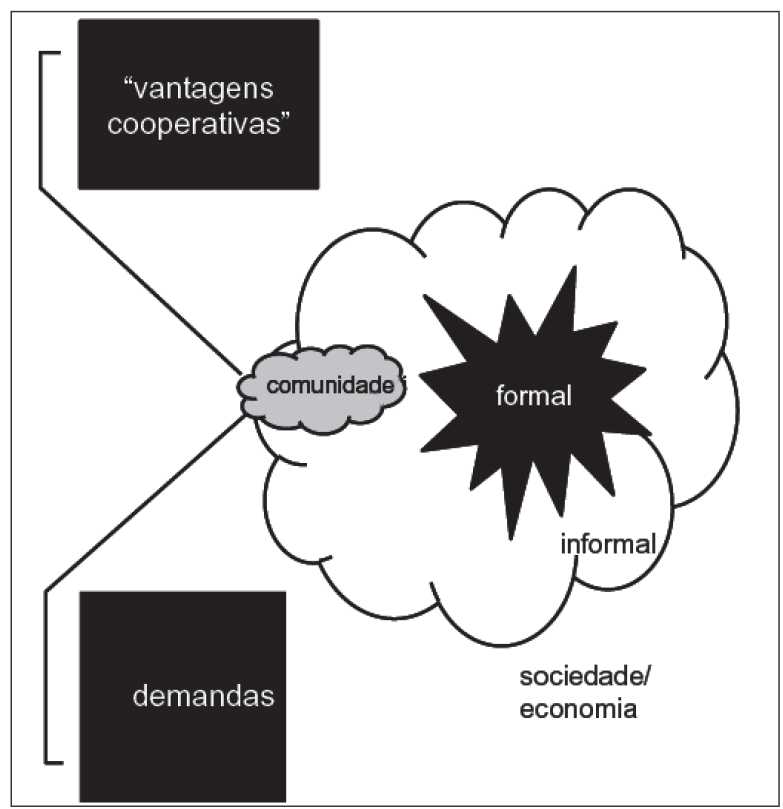

Para precisar o conceito de "vantagem cooperativa", tomei emprestado o termo "vantagem competitiva" usado por Porter (1993) ${ }^{36}$. Expandindo o tema da competitividade das empresas para o âmbito nacional, ele identifica quatro conjuntos de elementos que estariam na base da competitividade dos países:

1. Condições de fatores - referem-se à posição do país nos fatores de produção, como trabalho especializado ou infraestrutura, necessários à competição em determinada indústria;

2. Condições de demanda - tratam da natureza da demanda interna para os produtos ou serviços da indústria;

3. Indústrias correlatas e de apoio - análise da presença ou ausência, no país, de indústrias abastecedoras e indústrias correlatas que sejam internacionalmente competitivas (como indústrias correlatas, Porter qualifica aquelas em que empresas podem compartilhar atividades na cadeia de valores através das indústrias - canais de distribuição, desenvolvimento de tecnologia, ou

$36 \mathrm{O}$ trecho que segue, sobre o conceito de "vantagem cooperativa", foi desenvolvido por Rafael Dias, a quem agradeço. 
transferir conhecimentos protegidos pelo direito de propriedade de uma indústria para outra);

4. Estratégia, estrutura e rivalidade das empresas - dizem respeito às condições que, no país, regem e orientam a maneira pela qual as empresas são criadas, organizadas e dirigidas, mais a natureza da rivalidade interna.

A disposição desses quatro elementos, os determinantes das vantagens competitivas nacionais, na forma de um losango, deu origem ao que se tornou conhecido na literatura econômica como "o diamante de Porter".

Por analogia ao conceito de Porter, e apenas para tentar avançar na formulação do conceito de vantagens cooperativas, poder-se-ia propor que ela teria por base os seguintes elementos:

1. Capacidades dos trabalhadores, entendidas como habilidades reais e potenciais que possibilitem a implementação de formas coerentes com os princípios da ES e da TS na comunidade "i";

2. Demanda, entendida como a demanda real e potencial da comunidade "i", de outras comunidades da economia informal (ou da ES) e do mercado (economia formal) pelos bens e serviços passíveis de serem produzidos;

3. Relação com outras ES, entendida como a viabilidade de complemento à jusante ou à montante e adensamento de cadeias produtivas com outros empreendimentos solidários;

4. Sustentabilidade das ES, entendida como a capacidade das ES existentes ou a serem criadas para sobreviver frente à economia formal.

O elemento "Demanda" foi associado ao de "Condições de Demanda", proposto por Porter que o limita a um dado externo e de certa forma independente do país (ou da empresa) analisado. No caso que estou tratando, das "vantagens cooperativas, isso não deve ser assim. $\mathrm{E}$, por isso, esse elemento não pode ser considerado como algo dado para a comunidade "i”. Principalmente, ainda que não exclusivamente, porque ela apresenta, além de elementos que conformam o seu "diamante" de possibilidades de produção de bens e serviços, demandas materiais associadas a problemas sentidos pelos seus membros (omito, para simplificar a explicação do procedimento a ser seguido, aquelas demandas de natureza coletiva às quais me referi). 
É também para simplificar a explicação proporcionando uma via mais intuitiva para o entendimento do procedimento, que inicio, como mostra a figura 3, pela identificação de uma demanda material hipotética por água potável. Contrário, neste caso a ordem da exposição, não iniciando pela identificação das "vantagens cooperativas" como talvez fosse mais adequado.

O processo de especificação ou classificação que será utilizado, também, no caso das "vantagens cooperativas", está indicado na figura que envolve a listagem dos elementos ou atividades em que se deve decompor a satisfação da demanda de água potável (captação, tratamento etc.).

Figura 3 - Água potável

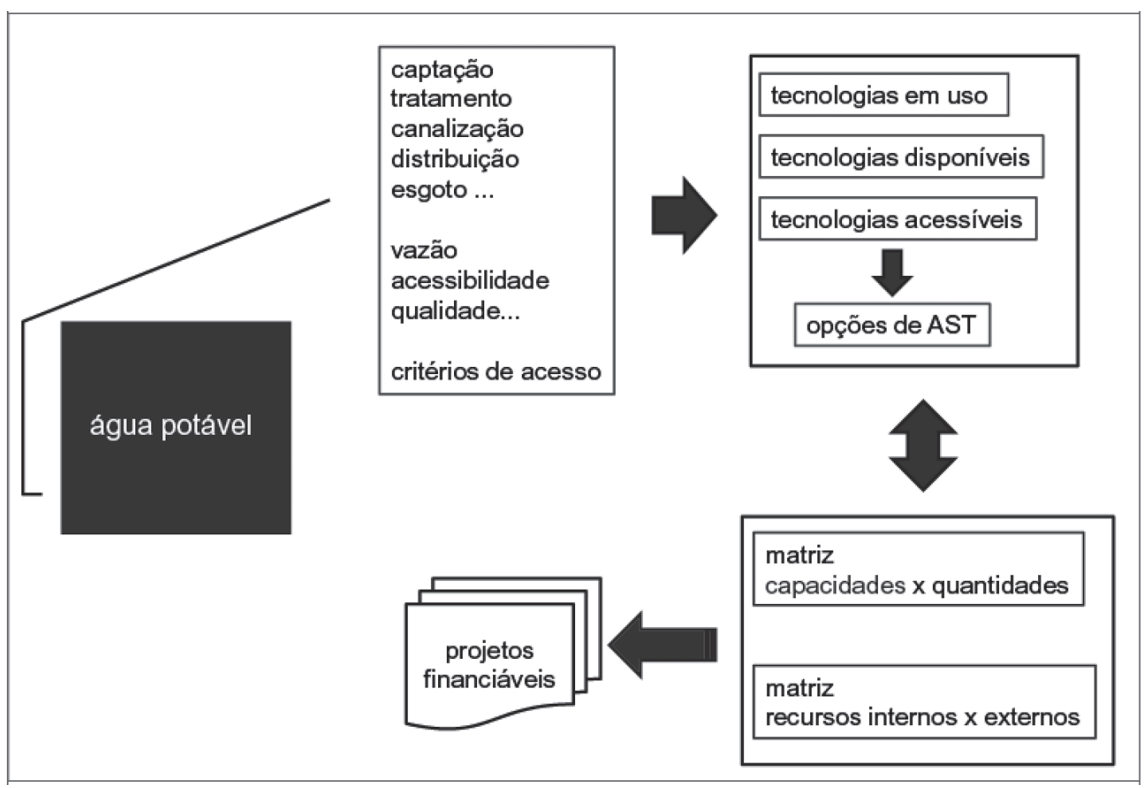

O processo ilustrado, na figura, indica as "perguntas" que tipicamente deveriam ser "feitas" a cada uma das atividades em relação às tecnologias correspondentes, de modo a orientar ações de AST.

Resumindo, o foco do levantamento de demandas deve estar em: (1) demandas materiais (valores de uso) das classes subalternas visando atendê-las mediante a sua participação no desenvolvimento de tecnologia e de sua utilização na produção; (2) bens e serviços de uso coletivo de responsabilidade do Estado, que não devem "passar pelo mercado" e que podem ser produzidos por empreendimentos solidários com TS. 
A figura 4 ilustra o processo de levantamento das "vantagens cooperativas". Ele se inicia com a identificação preliminar e a observação das atividades usualmente levadas a cabo na comunidade. Radicalizando, poderia dizer que a pesquisa sobre as "vantagens cooperativas" teriam que incluir desde as capacidades, habilidades e saberes das velhas bordadeiras que trabalham na elaboração de rendas de bilro até aquelas dos jovens envolvidos com o crime organizado.

A prospecção e "mineração" de outras "vantagens cooperativas" é uma atividade suplementar necessária para ampliar o leque de capacidades da comunidade passíveis de serem utilizadas. Sua realização se verá facilitada caso já se tenha uma razoável ideia acerca de quais demandas identificadas mereceriam atenção imediata.

Figura 4 -Vantagens Cooperativas

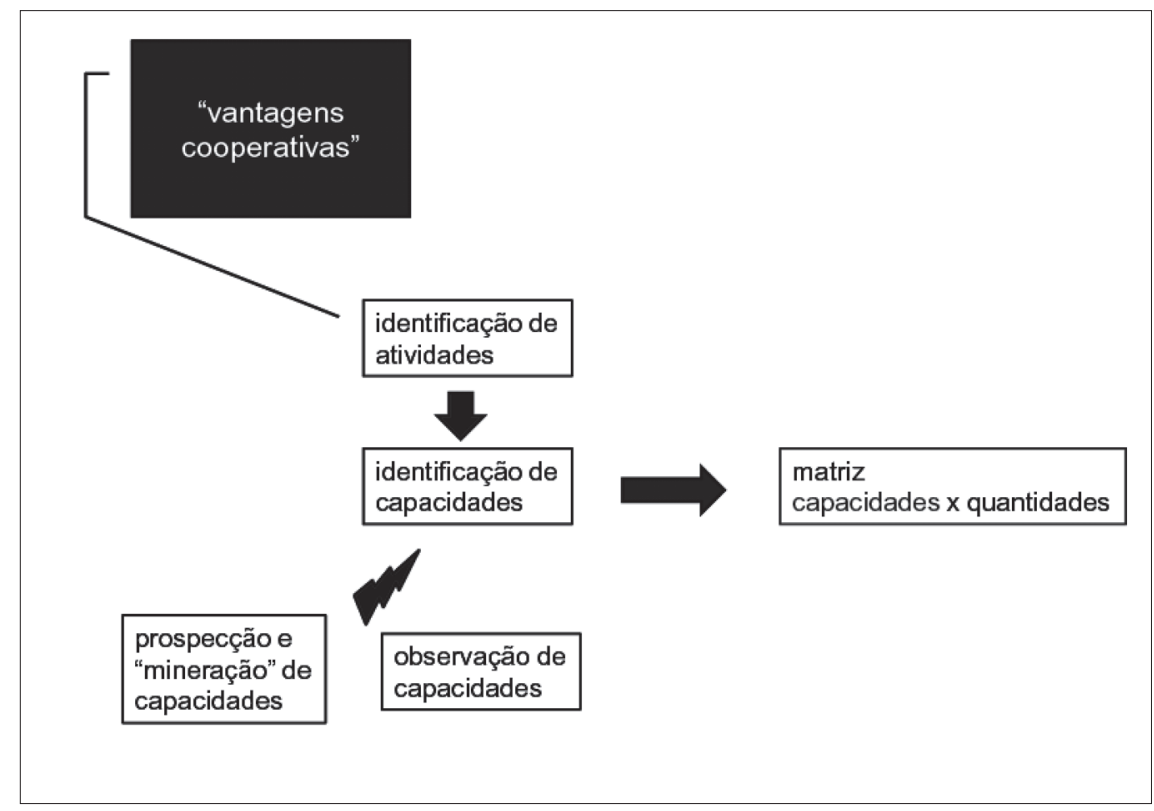

\section{Considerações finais}

A tipologia das seis situações típicas e os procedimentos de avaliação das "vantagens cooperativas" e das demandas relacionadas a uma dada comunidade situada na economia informal compõem um conjunto a ser utilizado para orientar a escolha de oportunidades de AST. Esse conjunto irá indicar em cada circunstância concreta a melhor forma de promover a expansão da ES e as providências que deverão ser tomadas para que 
uma atividade (ou cadeia produtiva) pertencente à economia formal seja incorporada à ES ou vice-versa.

A natureza dessas providências dependerá de uma decisão acerca de qual limite ou gradiente deverá concentrar os esforços visando a sua alteração e da consideração das "vantagens cooperativas" e demandas. Em outras palavras, a ação de expandir o espaço da ES "invadindo" a economia formal, ou de impedir a captura de alguma atividade ali realizada pela economia formal, depende da consideração por parte da comunidade acerca do conjunto formado pelos três procedimentos. A decisão acerca das situações típicas (Qual delas é possível atuar? Sobre qual delas temos maior governabilidade? Qual delas é conveniente atacar em primeiro lugar?) deve ocorrer em paralelo ao emprego dos outros dois procedimentos.

Cabe ressaltar que o que acabo de descrever, embora se assemelhe mais a um conjunto de recomendações para a ação concreta dos partidários da ES visando à exploração de oportunidades de AST e ao desenvolvimento de TS (e, na verdade ele poderia ser usado com este objetivo), ele pretende ser um guia para a escolha de processos a observar ou "casos" a estudar. A ideia é, então, conferir prioridade a casos em que uma análise iterativa da tipologia das seis situações típicas e dos procedimentos de avaliação das "vantagens cooperativas" e das demandas de uma dada comunidade, isto é, do conjunto sugerido, indique um balanço favorável.

Em ambos os casos, quer se trate de uma ação concreta ou de uma atividade de pesquisa, um passo importante seria a elaboração de uma matriz de "vantagens cooperativas" (capacidades ou potencialidades) e respectivas quantidades que seriam necessárias para a satisfação das demandas materiais identificadas. Embora essa tentativa de compatibilização ou ajuste entre o "lado da oferta" ("vantagens cooperativas") e o "lado da demanda" (demandas materiais identificadas) esteja referida como algo a posteriori, como um resultado de dois levantamentos anteriores, é compreensível que os três procedimentos devam ser realizados em paralelo, como um conjunto.

Isso posto é possível avançar um pouco mais na explicitação da metodologia que está sendo construída. Para isso, há que lembrar que a ideia é promover um processo de compatibilização ou ajuste que se assemelhe ao movimento de coorganização (ou auto-organização) que originou o trânsito da economia informal para a formal ao longo da expansão do modo de produção capitalista. Movimento que, evidentemente, não ocorreu como o resultado do que aqui estamos decompondo em três momentos: identificação de demandas e de "vantagens cooperativas", e 
compatibilização ou ajuste. $\mathrm{O}$ fato de que o processo que se está tratando deva ter um grau de racionalidade e intencionalidade superior, sobretudo porque se trata de um movimento contra-hegemônico, não deve implicar que se entenda os dois momentos como independentes e o terceiro como necessariamente posterior a eles.

O processo de compatibilização ou ajuste se processa a partir das matrizes relacionando as "vantagens cooperativas" da comunidade analisada e as quantidades associadas às demandas materiais identificadas. A consolidação de todas essas informações em projetos a serem financiados pelo Estado é o último e indispensável passo a ser dado.

A esse respeito, convém lembrar que, embora se costume ressaltar que os ESs devem ser sustentáveis (econômica, social e culturalmente) para poderem se liberar de sua sujeição ao Estado, para assim não se subordinar a suas normas discriminatórias, sobreviver sem o aporte de recursos públicos, manter seus valores e práticas, não se deve esquecer de que a empresa privada não sobrevive sem o Estado. É ele que produz a estrutura econômico-produtiva (comunicação, transporte, energia etc.) e regula a legalidade (financiamento, impostos, preços, subsídios, salários etc.) que viabilizam a atuação das empresas e asseguram o lucro. Além do que é o Estado que cria e sustenta os arranjos institucionais que produzem o conhecimento incorporado - no sistema de ensino e pesquisa, em artefatos tecnológicos e em mão de obra qualificada - e desincorporado - a C\&T - necessário à operação das empresas. É também o Estado que engendra e mantém a superestrutura político-ideológica que assegura (e naturaliza) as relações sociais de produção assimétricas e antagônicas imprescindíveis para a reprodução do capital e socorre as empresas, injetando recursos quando "necessário", ou lhes concede favores suplementares quando as outras funções não geram condições suficientemente atrativas.

Por isso, é economicamente justificável e socialmente legítimo que a ES e os ESs que brotam da economia informal contem com um apoio do Estado proporcional à parcela da PEA que neles buscam meios para sobreviver ou, pelo menos, ao volume de recursos que operam.

Voltando à construção da metodologia, é conveniente salientar que as atividades AST devem situar-se na intersecção de dois planos. Um, que se encontra na base física das demandas materiais de comunidades excluídas e dos bens e serviços de natureza coletiva, que não devem passar pelo mercado e que podem por elas ser produzidos. Outro, também dado, em que se situam as potencialidades cognitivas, organizacionais e também fisicas que constituem as "vantagens cooperativas" dessas comunidades. Em outras palavras, e sendo mais normativo, as atividades AST devem materializar 
a vocação "costuradora" de combinar o objetivo de solucionar problemas locais sentidos por comunidades excluídas (ou pela coletividade mais ampla, que cabe ao Estado providenciar utilizando seu poder de compra) com as suas próprias habilidades, saberes, idiossincrasias e visões de mundo. A AST, então, supõe conceber atividades com características específicas, fortemente aderentes a esses dois conjuntos de condicionantes e às oportunidades de compatibilização ou ajuste.

Há que voltar um pouco atrás, agora, para retomar a consideração do primeiro componente tratado, aquele referente às seis situações típicas desencadeadoras do trânsito do capital entre a economia formal e a informal. Ou, melhor dizendo, para incorporá-lo ao conjunto de quatro procedimentos que, finalmente, consubstanciam a metodologia aqui proposta.

A figura 5 proporciona uma imagem dos atributos de interatividade e iteratividade, que correspondem à ideia de momento ${ }^{37}$, dos quatro procedimentos que integram a metodologia.

Figura 5 - Os quatro procedimentos da metodologia

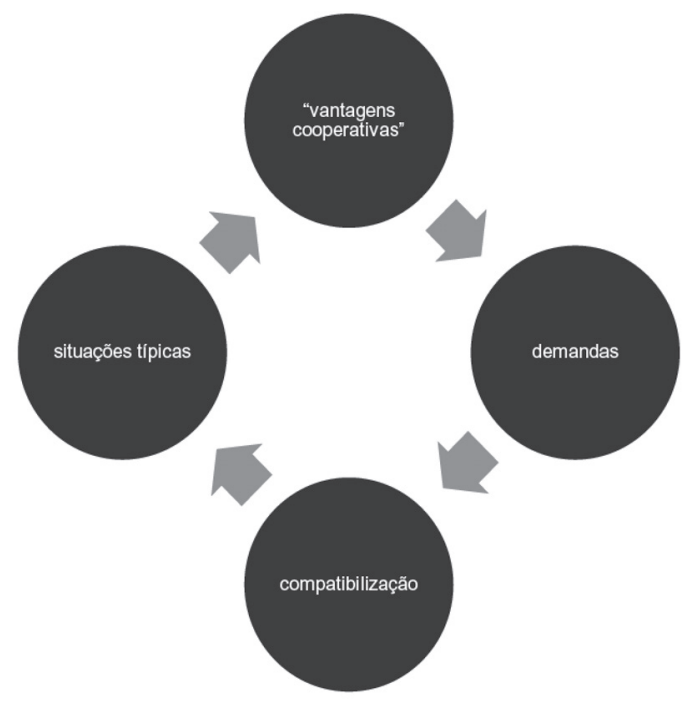

37 CILIERS, P. Complexity and postmodernism: understanding complex systems. London: Routledge, 1998.;DAGNINO, R. Neutralidade da ciência e determinismo tecnológico. Campinas, SP: UNICAMP, 2008. .O Campeonato mundial da ciência. Economia e Tecnologia. São Paulo, nv.5, n.17, abr.-jun., 2009.Disponível em: $<$ http://www.economiaetecnologia.ufpr.br/revista/17\%20Caoa/Renato\%2Dagnino. pdf $>$.HUGHES,T.J.West Antarctida ice streams. Review of geograpgysics and space physics. New York, v.5, p.1-46, 1977.; The jacobshavans effect. Geographycal Research Letters. New York, v.13, p.46-48, 1986. ; SACHS, Wolfgang. Dicionários do desenvolvimento. Rio de Janeiro:Vozes, 2000, p. 55 
Uma última consideração diz respeito ao princípio de economicidade que deve orientar o trabalho de pesquisa. E que aumenta a efetividade de nossa energia intelectual, física e financeira para situações (casos) em que o balanço entre esses dois conjuntos (ou a intersecção daqueles dois planos) seja o mais possível iluminador de caminhos de AST passíveis de serem aproveitados em outras iniciativas. $O$ que significa, em outras palavras, que nossa atenção deve estar focada prioritariamente na análise de situações em que a combinação - invertendo agora a ordem, uma vez que parece ser esta a metodologicamente mais apropriada - entre as potencialidades da comunidade (que por as possuírem deveriam ser escolhidas) e as demandas materiais a serem satisfeitas.

\section{Referências}

AQUINO, Israel Fernandes de; CASTILHO JR., Armando Borges de.; PIRES, Thyrza Schlichting De Lorenzi. A organização em rede dos catadores de materiais recicláveis na cadeia produtiva reversa de pós-consumo da região da grande Florianópolis: uma alternativa de agregação de valor. Gest. Prod. [online], vol.16, n.1, p. 15-24, 2009.

BORGES, Jorge Luís. A Memória de Shakespeare. In: OBRAS COMPLETAS. São Paulo: Globo, 1999.

BOSI, Antônio de Pádua. A organização capitalista do trabalho "informal": o caso dos catadores de recicláveis. Rev. bras. Ci. Soc. [online]. v.23, n.67, p. 101-116, 2008. Disponível em: < http://www.scielo.org/cgi-bin/wxis.exe/ applications/scielo-org/iah/?IsisScript $=$ iah/iah.xis\&base $=$ article ${ }^{\wedge}$ dart .

GRAY, John. Cachorros de palha. São Paulo: Record, 2006, PORTER, M. E. A vantagem competitiva das nações. Rio de Janeiro: Editora Campus, 1993. 